\title{
Religious Language Games
}

Alan Keightley, in Wittgenstein, Grammar and God, identifies a group of 'devout Wittgensteinians’ including some of Wittgenstein’s students, such as Rush Rhees and Norman Malcolm, and some of those who have been closely associated with the work of Wittgenstein’s pupils, including Peter Winch and D.Z. Phillips. ${ }^{1}$ These and like-minded thinkers have come to form what might be called 'the Wittgensteinian school of philosophy of religion'. One feature of the writings of members of this 'school' is that they make use of a theoretical vocabulary that is derived from the writings - and, in particular, the later writings_of Wittgenstein: 'language game', 'form of life', 'grammatical observation’, 'philosophical grammar', 'depth grammar’, and the like. While there are differences in the views of the members of the 'school', there are also many important similarities. In particular, members of the 'school' are agreed that religion constitutes a 'form of life', and that 'the religious language game' has a unique 'grammar' that is utterly misrepresented in standard philosophical discussions of religion and religious belief.

Critics of 'the Wittgensteinian school of philosophy of religion' are apt to complain that the crucial theoretical vocabulary involved in these formulations is, at best, “obscure and ambiguous". ${ }^{2}$ While the key terms are undeniably theoretical-they are,

\footnotetext{
${ }^{1}$ Alan Keightley, Wittgenstein, Grammar and God (London: Epworth Press, 1976), p.12. D.Z. Phillips provides a short list of works influenced by Wittgenstein in the philosophy of religion, in Belief, Change and Forms of Life (Basingstoke: Macmillan, 1986), pp.131-33.

2 See, for example, Anthony Kenny's criticisms in “In Defence of God,” Times Literary Supplement, 7 February 1975, p.145; quoted in Richard Messer, Does God's Existence Need Proof? (Oxford: Clarendon Press, 1993), p.61.
} 
after all, the terms of art of a particular philosophical movement-there is nowhere that they have ever been given a satisfactory explication. Moreover-and perhaps more importantly_even if we suppose that we can give sufficient sense to this theoretical vocabulary, it seems clear that there are competing theories, couched in terms of alternative vocabularies, that should be preferred because of their greater explanatory scope, explanatory power, advancement of understanding, and so forth.

The force of this complaint is perhaps best brought out by consideration of examples. Take the relationship between knowledge and belief as a test case. Many philosophers have supposed that knowledge entails belief: one can only know that $p$ if one believes that $p$. Against this, members of 'the Wittgensteinian school of philosophy of religion’ object that this remark misconstrues ‘the grammar of our language': for, in circumstances in which it is true that someone knows that $p$, it would be entirely inappropriate to say that that person believes that $p$, whence it follows that it is just a mistake to suppose that knowledge entails belief.

There is, of course, at least one well-known response to this 'grammatical' objection. As Grice pointed out, it is plainly true that there are various 'conversational maxims' to which we are enjoined to conform, and which we can exploit in order to achieve conversational ends. ${ }^{3}$ One of these maxims is that, other things being equal, one ought to make one's conversational contribution such that one conveys all of the relevant information that one has at one's disposal. Applied to the case at hand, this means that if one is in a position to say that someone knows that $p$, then one ought not only to make the

\footnotetext{
3 See Paul Grice, Studies in the Way of Words (Cambridge, MA: Harvard University Press, 1989), esp. ch.
} 2. 
weaker claim that that person believes that $p$-because, in the circumstances, one's failure to say that the person knows that $\mathrm{p}$ will then be taken as an indication that the person does not know that $p$, but rather only believes that $p$.

Once we see that we can have conversational reasons for refraining from the assertion of claims that we nonetheless take to be true, we also see that the 'grammatical observation' made by members of 'the Wittgensteinian school of philosophy of religion' can only establish the claim that knowledge does not entail belief if there are reasons to prefer the theoretical apparatus invoked by the members of 'the Wittgensteinian school of philosophy of religion’ to the Gricean theory of conversational implicature. Moreover, when we think about the relative merits of the competing theoretical accounts, it seems clear that it is the Gricean theory that ought to be preferred. After all, only the Gricean theory issues in clear predictions that are verified in case after case; and only the Gricean theory can be plausibly incorporated into a plausible broader theory of linguistic and conversational competence. While genuine philosophical understanding issues from the Gricean theory, the Wittgensteinian talk of 'grammatical observations' is theoretically sterile, and resists incorporation into broader theories of linguistic and conversational competence. $^{4}$

There are strands of thought in 'the Wittgensteinian school of philosophy of religion' that have been more widely adopted in recent times. In particular, there are clear

\footnotetext{
${ }^{4}$ Our main objection here is to the particularism that is inherent in the Wittgensteinian approach. While the Wittgensteinian is obliged to treat the interaction of 'belief' and 'knowledge' as a unique case that can only be understood by careful examination of the 'form of life' in which talk about belief and knowledge has its home, the Gricean has a theory that predicts the details of the interaction on the basis of a small number of very general 'maxims' of conversation. While the Wittgensteinian might insist that s/he can "predict" linguistic behaviour on the basis of her careful examination of appropriate "forms of life", there is just no comparison between the predictive sweep of the Gricean theory and the myopic particularism of the Wittgensteinian approach.
} 
affinities between the theoretical apparatus of 'language games' and 'forms of life', and the theoretical apparatus of 'domains of discourse' adopted by Crispin Wright. ${ }^{5}$ Each of these cases is characterised by espousal of a theoretical pluralism about central vocabulary. For Wright, the crucial case is truth: his claim is that truth is formally uniform - in the sense determined by satisfaction of various key platitudes concerning truth—but that its constitution may vary depending on the type of statement and subjectmatter concerned. This theoretical pluralism about truth seems to be central to the thought of 'the Wittgensteinian school of philosophy of religion', but, in this case, the theoretical pluralism is also extended to the full family of transcendental notions: identity, existence, object, being, and so forth.

Wright's argument for pluralism about truth depends upon an analogy with identity. In that latter case, it seems quite plausible to claim that, while the formal properties of identity are invariant across the full range of discourses, the constitution of identity varies according to the subject-matter under consideration: material objects, numbers, directions, people, and so forth. However, there is a central disanalogy which threatens to cripple Wright's argument at this point, namely that, while there are considerations about 'identity under a sortal' that make it plausible to claim that there is diverse constitution of identity, there are no similar considerations about 'truth under a sortal'. We can sensibly ask whether this is the same cow/number/person/etc. as the one we encountered previously. But there is no corresponding formulation-no corresponding thought - in the case of truth. A plausible consequence here is that,

\footnotetext{
${ }^{5}$ See Crispin Wright, Truth and Objectivity (Cambridge, MA: Harvard University Press, 1992).
} 
Wright's protests to the contrary notwithstanding, his pluralism about truth is defeated by considerations concerning 'mixed' discourses and 'mixed' inferences.

Consider, for example, the inference from 'He lives in a beautiful Edwardian house' to 'He lives in an Edwardian house'. This inference moves from a sentence that contains an evaluative predicate—and hence which, plausibly, belongs to evaluative discourse - to a sentence that contains no evaluative predicates, and which, plausibly, belongs to straightforward fact-stating discourse. If we suppose that there really are distinct truth predicates that are appropriate to evaluative (aesthetic) and non-evaluative discourse, then it is very hard to see how the inference in question could be justified. Multiplication of examples such as this one strongly suggests that pluralism about truth is simply a mistake (and, if we give up on pluralism about truth, then, very plausibly, pluralism about at least some of the other transcendental notions must also be relinquished).

The above pair of criticisms of the members of 'the Wittgensteinian school of philosophy of religion' — viz., that they are committed to an indefensible pluralism about truth and at least some other transcendental notions, and that their central method of argumentation is vitiated by a refusal to attend to the evident consequences of Grice's work on conversational implicature—proceed at a highly theoretical level, and are not directly concerned with what these philosophers have to say about religion. However, as our subsequent discussion of the work of D.Z. Phillips indicates, disagreements between the members of 'the Wittgensteinian school of philosophy of religion' and their opponents typically turn on these kinds of highly theoretical disagreements, even when there are other kinds of less highly theoretical disagreements—-particularly concerning 
matters specific to religion and religious belief-in play. It is therefore important to remember that the vocabulary of 'language games', 'forms of life', 'grammatical observations', 'philosophical grammar', 'depth grammar', 'world views', and the like, is the vocabulary of a highly controversial philosophical theory; it does not constitute an incontestable framework within which discussion of questions about religion can straightforwardly proceed.

\section{D.Z. Phillips and the Metaphysical Reality of God}

God grant the philosopher insight into what lies in front of everyone’s eyes.

- Wittgenstein ${ }^{6}$

The most prominent member of 'the Wittgensteinian school of philosophy of religion' is undoubtedly D.Z. Phillips. In what follows, we examine two important and related aspects of his perspective on religious language. We begin with Phillips' critique of the traditional philosophical understanding of God as a 'metaphysically real' or ‘independently existing' being. We then consider his reasons for rejecting views of religious language which hold that such language is in some important respects 'factstating'.

Phillips strikes many as a perplexing figure. In a large body of work from the early 1960s, he has repeatedly argued in support of a conception of religious belief that is,

\footnotetext{
${ }^{6}$ Wittgenstein, Culture and Value, transl. Peter Winch (Oxford: Basil Blackwell, 1980), p.63. Although Phillips is fond of this quote, we will argue that he himself misses "what lies in front of everyone's eyes", viz., that religious beliefs do purport to state facts and to answer to metaphysical realities.
} 
in the eyes of most contemporary analytic philosophers of religion, downright mistaken. The following comments from Richard Swinburne typify this kind of response:

\begin{abstract}
Phillips’s account of religious language is subtle and coherently developed, reflecting Wittgenstein’s immense sensitivity to the different uses of language. It seems, however, to me to be in essence plainly false as an account of what the vast majority of normal users of religious language during the past two millennia have meant by the words and sentences which they have uttered. $^{7}$
\end{abstract}

Indeed, it is a mystery to many how Phillips could continue to advocate his conception of religious belief when the case against it appears to be so overwhelmingly strong. Phillips’ view of religious language, sometimes described as 'non-realist' or 'anti-realist" ${ }^{8}$, can be approached from a variety of directions, but one obvious entry point is to look at his critique of the traditional way philosophers have conceptualised God, that is to say, the God of the Abrahamic faiths.

Although philosophical conceptions of God vary widely, something approximating a consensus has emerged_-at least within analytic philosophy of religion - that God is best thought of as a perfect being, where to be perfect is to be the greatest being possible or, to borrow Anselm's well-known phrase, the being than which

\footnotetext{
7 Swinburne, The Coherence of Theism (Oxford: Clarendon Press, 1977), p.92.

8 Phillips, however, does not think of himself as a non-realist or anti-realist, for in his view "theological non-realism is as empty as theological realism” (“On Really Believing,” in Joseph Runzo (ed.), Is God Real? New York: St. Martin’s Press, 1993, p.87). But see Andrew Moore, Realism and Christian Faith: God, Grammar, and Meaning (Cambridge: Cambridge University Press, 2003), pp.80-92, where Moore argues that, despite Phillips' disavowal of non-realism in his more recent writings, Phillips “never quite succeeds in being a realist” (p.91).
} 
none greater can be conceived. ${ }^{9}$ Such a conception of God forms the starting-point in what has come to be known as 'perfect being theology'. ${ }^{10}$ On this view, one begins with the idea of God as maximally great or absolutely perfect, and then from this conception of deity one deduces all of God's core or essential attributes-i.e., those attributes which are constitutive of God's nature, so that he could not at the same time exist and lack any of these attributes. The claim, then, is that God can only be the greatest being possible in virtue of possessing every great-making quality or perfection to an unlimited degree ${ }^{11}$, where a quality may be said to be great-making insofar as it increases the degree to which the object to which it applies is worthy of worship and moral admiration. ${ }^{12}$ But to have all the great-making properties and to have them to an unlimited extent is to possess such attributes as maximal power (omnipotence), maximal knowledge (omniscience), and maximal or perfect goodness, as well as whatever attributes are entailed by these great-

9 See chapter 2 of Anselm's Proslogion, in Saint Anselm: Basic Writings, 2nd ed., trans. S.W. Deane (La Salle, IL: Open Court Publishing, 1962), pp.7-8. To be sure, the idea here is that God does not just happen to be the greatest conceivable being, but that this is a property he has essentially.

10 The foremost contemporary defender of perfect being theology is undoubtedly Thomas Morris-see his “Perfect Being Theology,” Noûs 21 (1987): 19-30; “Introduction” in Morris (ed.), The Concept of God (Oxford: Oxford University Press, 1987), pp.6-10; Anselmian Explorations: Essays in Philosophical Theology (Notre Dame, IN: University of Notre Dame Press, 1987), ch.1; and Our Idea of God: An Introduction to Philosophical Theology (Downers Grove, IL: InterVarsity Press, 1991), esp. ch. 2. See also George N. Schlesinger, New Perspectives on Old-time Religion (Oxford: Clarendon Press, 1988), ch. 1, esp. pp.16-21; Katherin A. Rogers, Perfect Being Theology (Edinburgh: Edinburgh University Press, 2000), esp. chs. 1 and 2, and Daniel J. Hill, Divinity and Maximal Greatness (London: Routledge, 2005).

11 This is not entirely accurate. As Schlesinger points out, “God's perfection cannot amount to His having each perfection-making attribute to the highest degree, since the maximization of some desirable qualities is incompatible with the maximization of others. Divine super-excellence is to be understood as the possession of each enhancing attribute to the precise degree required so that in combination they contribute to the maximum sum total of magnificence” (New Perspectives on Old-time Religion, p.1).

${ }^{12}$ We borrow here from Joshua Hoffman and Gary S. Rosenkrantz, The Divine Attributes (Oxford: Blackwell, 2002), pp.14-16, who take great-making to be a function of worship-worthiness and moral admirability. Morris, on the other hand, suggests that worship-worthiness "can be held to supervene upon, or to consist in, some of the properties ingredient in perfection” ("Perfect Being Theology," p.24). He then goes on to make perfection or greatness supervenient on intrinsic goodness or value, so that a great-making property is defined as one which is intrinsically good to have, and intrinsic goodness is in turn made a function of metaphysical status or stature ("Perfect Being Theology," p.26). 
making qualities. It is therefore thought that God's essential attributes can be distilled solely from the notion of God as an absolutely perfect being. These essential attributes include: omnipotence, omniscience, perfect goodness, aseity, incorporeality, eternity, omnipresence, perfect freedom, and creator and sustainer of all contingent things.

Various criticisms have been levelled against perfect being theology. It is sometimes objected, for example, that such a theology is liable to yield divergent conceptions of God when there is a clash of intuitions over which properties are greatmaking or over what is and is not a perfection. ${ }^{13}$ Phillips, on the other hand, objects to the idea of God as a perfect being on far more radical grounds. In particular, he takes issue with the very presupposition that God is a 'metaphysical reality', that is to say, a 'pure consciousness' that exists over and above all human consciousnesses.

Let’s backtrack a little, to 1975, to a conference organised by the Royal Institute of Philosophy at the University of Lancaster. ${ }^{14}$ Hick, Swinburne and Phillips were charged with discussing the problem of evil, and in the light of Phillips' response to Swinburne, Hick states that the differences between the two run quite deep. It is not simply that Swinburne advocates the construction of theodicies in the face of the world's evils while Phillips' rejects the project of theodicy-building. More importantly, they differ on the question of the very reality of God:

${ }^{13}$ See Brian Leftow, “God, Concepts of,” in E. Craig (ed.), Routledge Encyclopedia of Philosophy, vol. 2, p.97, and William J. Wainwright, "Worship, Intuitions and Perfect Being Theology,” Noûs 21 (1987): 3132. To be fair to Morris, however, he does not think of intuition as an infallible guide in this respect, but rather thinks that our intuitions on these matters may need to be reinforced or corrected by the data of revelation in conjunction with other methods for arriving at a religiously adequate conception of deity (see Morris, Our Idea of God, pp.41-45). Other criticisms of perfect being theology are addressed by Morris, "The God of Abraham, Isaac, and Anselm," in Anselmian Explorations, pp.13-25, and Schlesinger, New Perspectives on Old-time Religion, pp.16-21. 
For reading Phillips' paper, in the light of his other writings, I take it that he denies the existence of an all-powerful and limitlessly loving God. I take it, that is, that he denies that in addition to all the many human consciousnesses there is another consciousness which is the consciousness of God, and that this God is the creator of the universe and is both all-powerful and limitlessly loving. I take it that he rejects this belief as a crude misunderstanding of religious language and holds that, rightly understood, the 'existence of God' consists in man's use of theistic language within the context of a pattern of religious life. ${ }^{15}$

\title{
Phillips' response to the question of whether "in addition to all the many human consciousnesses there is another consciousness which is the consciousness of God” is revealing:
}

I can only reply, with Charles Hartshorne, in words that could have come equally from Wittgenstein: "Confusion in the posing of a question generates confusion in the answering of it." In speaking of "consciousness" in the way he does, Hick not only reifies an idea, an accusation Feuerbach might have made of him, but reifies a confused idea. So I do not deny it; it is not intelligible enough to deny. ${ }^{16}$

\begin{abstract}
Remarks such as these have given Phillips a reputation for evasiveness and obscurity. Stephen Davis, for example, writes in exasperation:
\end{abstract}

\footnotetext{
14 The proceedings of this conference are published in Stuart C. Brown (ed.), Reason and Religion (Ithaca, NY: Cornell University Press, 1977).

15 Hick, “Remarks,” in Brown (ed.), Reason and Religion, p.122.

16 Phillips, “Theism without Theodicy,” in Stephen T. Davis (ed.), Encountering Evil: Live Options in Theodicy, 2nd ed. (Louisville, KY: Westminster John Knox Press, 2001), p.153.
} 
I simply want to insist that Phillips knows good and well what Hick was driving at - as I do and as everybody else does - and that Hick’s question deserves a straight answer. ${ }^{17}$

Phillips’ reply is again revealing:

Really? I do not think Hick can say what he means. And how can Davis, since he does not “deny that there are conceptual problems” with talk of the consciousness of God. Conceptual problems are problems of intelligibility. Davis says that I say “somewhat petulantly that [Hick’s] statement ‘is not intelligible enough to deny'.” But that statement is the conclusion to arguments. Davis ignores them... 18

Phillips' view, then, is that the traditional philosophical understanding of God—one might say the 'realist' view of theistic discourse-according to which God is an incorporeal person-like being who exists objectively or independently of any creature, is committed to the notion of God as a pure consciousness, a notion that ought to be rejected as conceptually confused. How, then, does Phillips reach this conclusion? In a recent discussion of Wittgensteinianism in the philosophy of religion, Phillips notes that the twentieth century witnessed a revolution in philosophy led largely by

17 Davis, “Critique [of Phillips" “Theism without Theodicy”],” in Davis (ed.), Encountering Evil, p.168. Phillips' refusal to supply 'a straight answer' has led some to suspect that he is 'deep down' an atheist. Consider, for example, the following humorous gloss on the exchange between Phillips and Hick:

Hick wants to say Phillips can't get away with claiming to believe in God. 'You can't fool us Phillips', I hear Hick saying, 'when you talk about God moving upon the face of the waters. You don't believe in God, you only believe in your feelings aroused by the view of Swansea Bay from your study window.' Phillips asks: well then, what must I do to be believed that I believe? You must admit 'God exists' is a proposition, Hick says, and accept the responsibility for proving it.

(Alfred Louch, “Saying is Believing”, in Runzo (ed.), Is God Real? p.110)

18 Phillips, “Rejoinder,” in Davis (ed.), Encountering Evil, p.176. See also Phillips, The Problem of Evil and the Problem of God (London: SCM Press, 2004), p.152. 
Ludwig Wittgenstein. ${ }^{19}$ On Phillips’ account, the revolution was sparked by Wittgenstein's critique of Descartes' epistemological legacy, a legacy which—Phillips adds—most contemporary philosophers of religion have uncritically inherited. According to Phillips, a crucial element of the Cartesian legacy is the gap it opens up between consciousness—or thought, or ideas, or mind—and a mind-independent reality. What worried Descartes, in Phillips’ view, is: How, from inside my consciousness, can I make contact with a reality outside it? ${ }^{20}$ On Phillips' account of the Cartesian view, this gap between consciousness and reality is reflected in the idea of God as a metaphysical reality existing beyond all human consciousnesses. Phillips argues, however, that the import of the Wittgensteinian revolution is that such an idea of God must be deemed unintelligible, the product of confusion.

Phillips subjects the metaphysically real God to a fourfold critique. His first objection emerges from a critique of "the empiricist notion of ideas", i.e., the view that we are not immediately acquainted with the world, but rather are only ever immediately acquainted with our ideas. Phillips writes:

God as a pure consciousness, pre-existing all things, is said to have ideas and to entertain thoughts. But what makes these ideas and thoughts what they are? The logical difficulties inherent in the

\footnotetext{
19 Phillips, “Wittgensteinianism: Logic, Reality, and God,” in William J. Wainwright (ed.), The Oxford Handbook of Philosophy of Religion (Oxford: Oxford University Press, 2005), pp.447-71. Much of this material is included in ch. 2 of Phillips' Religion and Friendly Fire: Examining Assumptions in Contemporary Philosophy of Religion (Aldershot: Ashgate, 2004).

${ }^{20}$ Phillips, “Wittgensteinianism,” p.450.
} 
empiricist notion of “ideas” reemerge, difficulties encapsulated in Wittgenstein’s arguments against a logically private language. ${ }^{21}$

The reference to the private language argument advanced by Wittgenstein in the Philosophical Investigations may seem puzzling at first, for that argument is directed against the idea of an essentially private language. Wittgenstein describes such a language in the following terms:

The individual words of this language are to refer to what can only be known to the person speaking; to his immediate private sensations. So another cannot understand the language. ${ }^{22}$

What Wittengenstein is describing here is a language which is in principle incomprehensible to everyone other than the user of the language in question, and its comprehensibility is limited in this way because the meanings of its putative signs are inaccessible to everyone bar the individual language-user. But the ideas and thoughts of God, considered as a metaphysically or mind-independently real subject, need not be inaccessible in principle to others. Indeed, theists commonly speak of God as revealing his plans, intentions and commands to his creatures, and it would make no sense to speak of God in this way unless it was assumed that God's plans, intentions and commands could be understood by his creatures. Phillips, however, is aware of this sort of reply, and counters it as follows:

\footnotetext{
21 Ibid., p.456.

${ }^{22}$ Wittgenstein, Philosophical Investigations, trans. G.E.M. Anscombe (Oxford: Blackwell, 1958$)$, §243.
} 
Nor will it do to say that God's thoughts and ideas need be only potentially shareable, not actually shared, since this will not secure the essential distinction between "following a rule" and "thinking one is following a rule”, between "getting it right" and "thinking one has got it right"... For the idea that the rule is intelligible prior to its having a common use, would require the rule to provide, without such mediation, its own application. To postulate a rule for the use of the rule would leave us with the same problem, plus the prospect of an infinite regress. To know whether an individual is following a rule correctly, there must be a context other than the individual user in which a distinction between correct and incorrect has a purchase. ${ }^{23}$

Phillips is here endorsing the so-called 'Community View' espoused by-among others-Rush Rhees ${ }^{24}$ and Norman Malcolm ${ }^{25}$, according to which the concept of following a rule presupposes a community in which there is agreement as to whether doing such-and-such counts as following a particular rule. On this view, as Malcolm explains, "to follow the rules for the use of an expression is nothing other than to use the expression as it is ordinarily used-which is to say, as it is used by those many people who take part in the activities in which the expression is embedded.”26 Rule-following therefore makes sense only against the background of a shared linguistic practice, so that one can be judged to be correctly following a rule with respect to one's use of language only if one's linguistic usage conforms to the prevailing pattern of use as exemplified by one’s fellow language-users. If, for example, I never participate in a communal linguistic

\footnotetext{
${ }^{23}$ Phillips, “Wittgensteinianism,” pp.456-57.

${ }^{24}$ See Rush Rhees, “Can There Be a Private Language?” Proceedings of the Aristotelian Society, suppl. vol. 28 (1954): 77-94.

${ }^{25}$ See Norman Malcolm, Nothing is Hidden: Wittgenstein's Criticism of his Early Thought (Oxford: Blackwell, 1986), ch. 9, and “Wittgenstein on Language and Rules,” Philosophy 64 (1989): 5-28.

${ }^{26}$ Malcolm, “Wittgenstein on Language and Rules,” p.22.
} 
practice, so that I 'make up the rules as I go along', then the crucial distinction between my following a rule and my thinking I am following a rule would be lost. As Wittengenstein points out in a related context, "in the present case I have no criterion of correctness. One would like to say: whatever is going to seem right to me is right. And that only means that here we can't talk about 'right'., ${ }^{27}$ Thus, to secure the objectivity of my judgments regarding what words or sentences mean, linguistic rules and meanings must be independent of me, or of any particular person. ${ }^{28}$

The implication Phillips draws from this is that God, conceived of as a solitary pure consciousness pre-existing all other consciousnesses, cannot intelligibly be thought of as having thoughts and ideas, or perhaps any mental life at all. According to Phillips, not even God could know what is expressed by God's own ideas and thoughts. Given that God is a solitary rule-follower and not a member of a community of language-users who act in accordance with rules, there can be no fact of the matter as to what the internal vehicles of God's musings signify. But what exactly are the internal vehicles of God's musings? It would be grossly anthropomorphic to think of God as literally using words or speaking in some human language. (This is not to say that God cannot inspire people to express his intentions or commands in human language, but this is not the same as saying that God himself uses human language.) God may, nevertheless, have ideas or thoughts, but here too Phillips would stress the logical dependency of thoughts on communal practices: just as we need to defer to community practices in order to individuate linguistic rules and meanings, so too the very possibility of having an 'inner life' of ideas

\footnotetext{
27 Wittgenstein, Philosophical Investigations, §258; cf. §202.

${ }^{28}$ See Malcolm, “Wittgenstein on Language and Rules,” p.22.
} 
and thoughts depends on there being shared activities and a language which people have in common. It is precisely for this reason that Phillips, in Death and Immortality, rejects the view that to survive death is just to survive as a disembodied soul. This view, Phillips states, rests on a conception of the self as an inner thinking and necessarily private substance (viz., the soul). But private experiences and thoughts are logically parasitic on public meanings, and so the former cannot be divorced from the latter. ${ }^{29}$

The Community View, however, is not the only game in town. There are other, and perhaps more plausible, options, in particular the position advocated by G.P. Baker and P.M.S. Hacker. ${ }^{30}$ Taking their cues from Wittgenstein himself, Baker and Hacker argue that language does not presuppose a community. Their position, more precisely, is that language does not require a shared, community practice, but only a shareable one: "concept-possession, following a rule, mastery of a language presuppose not that these are shared with other people, but rather that they can be shared, that is must make sense for others to understand, agree on what counts as doing the same relative to a rule, follow the rule in the same way." ${ }^{31}$ On this view, whether one is correctly following a rule with respect to one's use of language is not determined by the extent to which one's usage agrees with shared community practice, but is rather determined by the rules themselves:

\footnotetext{
${ }^{29}$ See Phillips, Death and Immortality (London: Macmillan, 1970), pp.2-10.

${ }^{30}$ See G.P. Baker and P.M.S. Hacker, Scepticism, Rules and Language (Oxford: Blackwell, 1984), Wittgenstein: Rules, Grammar and Necessity. An Analytical Commentary on the 'Philosophical Investigations', volume 2 (Oxford: Blackwell, 1985), pp.169-79, and "Malcolm on Language and Rules," Philosophy 65 (1990): 167-79. See also John V. Canfield, “The Community View,” Philosophical Review 105 (1996): 469-88, which attempts to reconcile the Community View (that language is essentially communal) with the opposing Baker-Hacker view (that it is conceptually possible for a Crusoe isolated from birth to speak or follow rules). In fn. 2 of his paper, Canfield also helpfully provides a short bibliography of publications relating to this controversy.

${ }^{31}$ Baker and Hacker, “Malcolm on Language and Rules,” p.171, emphases in the original.
} 
"It is rules (charts, signposts, etc.) that are called 'standards of correctness', and it is they, and not some other thing, that are used as such." ${ }^{32}$ But if it is not a shared social practice, but the rule itself, which determines what counts as following a rule, then will the distinction between 'following a rule' and 'thinking one is following a rule' be jeopardised? Malcolm, and Phillips after him, holds that this distinction would have no application unless the rules are in fact shared, that is, actually held in common amongst some community of speakers. But as Baker and Hacker note, it makes sense to say that a Robinson Crusoe, who—unlike Defoe’s character—was stranded from birth till death on a deserted island, could invent a new card game and play it, where this includes making various mistakes in following the —unshared —rules of the game and subsequently noticing these mistakes and correcting himself. ${ }^{33}$ As long as the possibility of sharing one's understanding of the rules is maintained, there seems to be no logical objection to the idea of solitary rule-following. ${ }^{34}$

Phillips' second objection to the idea of God as a pure consciousness relates to issues of identity and individuation:

\footnotetext{
${ }^{32}$ Ibid., p.170, emphasis in the original.

33 Ibid., p.178.
}

${ }^{34}$ It may be objected that even the Baker-Hacker view causes trouble for the philosophical theist who is intent on holding onto a 'metaphysically real' God. For if one's language, concepts and thoughts must be shareable on pain of being unintelligible, what is the theist to say of those concepts and thoughts entertained by God which are so complex that they are, in principle, unshareable (i.e., they cannot be understood by anyone who is less than omniscient)? One possible response is to reject shareability as a constraint for the meaningful use of language, and although this might seem a quite radical response to the Community View, we are not convinced that such a response is entirely lacking in plausibility - for an early defence of this view, see A.J. Ayer, “Can There Be a Private Language?” Proceedings of the Aristotelian Society, suppl. vol. 28 (1954): 63-76. But even if shareability were accepted, one may propose to define 'shareability' in a species-relative way, so that one's language, concepts and thoughts need only be shareable by other (possible or actual) members of one's species. In the case of God, his thoughts would then need to be shareable only with other (possible or actual) divine beings-say, another member of the Holy Trinity, or a fictional god who happens to be omniscient. 


\begin{abstract}
“Consciousness” cannot yield the identity of its possessor. Consciousness cannot tell me who I am.
If it is supposed to pick me out, I'd need to experience a number of consciousnesses, which is absurd... I am who I am in a human neighborhood, as this person, not that one. But God has no neighbors. ${ }^{35}$
\end{abstract}

To have an identity, on this view, one must exist within a community. It is not entirely clear why Phillips thinks this, but the idea seems to be that any description we give that uniquely identifies some person, say, Socrates, must refer to properties that Socrates has and that all other people lack — and so reference, if only implicit, to others in the community cannot be avoided. However, the only properties that could play this role would be properties that belong to Socrates essentially, where Socrates’ essential properties may include such properties as being Socrates, having been born on such-andsuch day to such-and-such parents, having had a biography of such-and-such sort, and so on. Socrates, therefore, can know who he is by knowing what his essential properties are. But then God too can know who he is, and be uniquely identified by us, by knowing what his essential properties are. And while there may be some plausibility in the view that a human person's essential properties must make reference to other people-consider, for example, the essential origins thesis - there is no reason to think that God's essential

\footnotetext{
${ }^{35}$ Phillips, "Wittgensteinianism," p.457, emphases in the original. A further difficulty with this passage, in addition to the one we go on to mention in the main text, resides with the assumption that the defining feature of personal agency is consciousness. With this assumption in the background, Phillips states that, "If consciousness is the essence of a person, one would expect it, at the very least, to be the guarantor of that person's identity. But consciousness cannot tell me who I am” (The Problem of Evil and the Problem of God, p.152). However, it is far from clear that consciousness is the only essential property of personhood (persons, according to many, must also be capable of exhibiting a variety of mental states and be capable of acting intentionally). Further, Phillips is conflating the general question of what it is to be a person with the more specific question of what it is to be the particular person that I am.
} 
properties must make reference to other beings, whether they be of the same-divine- or different kind. Indeed, what are normally taken to be God's essential properties-e.g., omnipotence, omniscience, perfect goodness — can be understood without reference to any other beings.

Phillips' third objection runs as follows:

The divine consciousness is supposed to be the source of the reality of all things, but...this metaphysical space is an intellectual aberration. Consider such a space in the Pythagorean claim that numbers entail the existence of ultimate units, which are supposed to account for our actual arithmetical configurations. Granting that the units are mathematical, they cannot fulfill this metaphysical role, since arithmetic does not spring from the units like shoots from a bulb... ${ }^{36}$ It is not the units that give sense to the arithmetic, but the arithmetic that gives sense to the units... Similarly, it is not "consciousness", metaphysically conceived, that shows us what is meant by "the mind of God", but the religious practice in which that notion has its application. ${ }^{37}$

Just as the ultimate Pythagorean units were thought to account for-explain, give sense to-arithmetic, so the existence of God is thought to account for the reality of all things. For Phillips, however, this is all back to front: it is arithmetic that gives sense to the units, and it is everyday realities as expressed in our religious practices that give sense to our God-talk. There is no denying that we must often attend to the practices - and, in particular, the utterances_ — of religious believers if we are to properly understand their beliefs. But when believers profess that God is "the source of the reality of all things",

\footnotetext{
${ }^{36}$ Phillips here refers to an essay by Rush Rhees, “On Continuity: Wittgenstein’s Ideas, 1938,” in Rhees' Discussions of Wittgenstein (London: Routledge \& Kegan Paul, 1970), pp.104-57, where similar sentiments are expressed—see esp. p.114.

37 Phillips, “Wittgensteinianism,” p.457.
} 
their words are not mysterious or an "intellectual aberration”. It is, in fact, relatively easy to understand what they mean: the existence of the physical world and everything therein is ultimately dependent upon God, in the sense that God brought the world into being and conserves it in being at every moment. It is far from clear, contra what Wittgensteinians often say, that once we look to the believers' 'form of life' or religious practices, a very different account of 'God is the source of the reality of all things' will emerge.

The final criticism Phillips makes against the idea of God as a pure consciousness is that such an idea is explanatorily idle:

God's consciousness is often associated with the notion of a divine plan which is supposed to explain all things, but no actual explanation is advanced. If I say that something has happened in accordance with a plan, I can check to see whether what happened deviates from the plan. But if whatever happens is said to be in accordance with a plan, reference to a plan becomes superfluous, an idle wheel. ${ }^{38}$

But are theists — of the traditional philosophical sort—committed to the view that 'no matter what happens in the world, it can be said to be in accordance with God's plan'? Some theists, to be sure, do talk in this way, but there is no reason why they must. Consider, for example, the response given by many theists to Flew's infamous falsification challenge, the challenge of specifying circumstances which, had they obtained, would constitute compelling evidence against the existence of God. ${ }^{39}$ In

38 Ibid., p.457.

39 See Antony Flew, “Theology and Falsification,” in Antony Flew and Alasdair MacIntyre (eds), New Essays in Philosophical Theology (London: SCM Press, 1955), pp.96-99. 
response to this challenge, Colin Brown conceded that theism—or at least Christian theism—would be false if

suffering never proved to be a blessing in disguise. It would be false if adversity was never a means of finding a deeper meaning in life. It would be false if people had no experience of God working out a higher purpose in life. It would be false if adversity never offered others the opportunity of service and self-giving. It would be false if God had consigned all men to condemnation and had not sent his Son to redeem them. ${ }^{40}$

Most varieties of theism, particularly 'expanded' forms of theism that are part of a rich, historical religious tradition, make various predictions about what the world is like, and believers and non-believers can therefore 'check to see' whether those predictions turn out to be correct.

In the following section, we will look at Phillips' view that religious statements, such as 'God loves us' and 'God created the heavens and the earth', are not factual statements; that is to say, such statements do not purport to express facts in the same way as statements like 'It is raining today' and 'She won the lottery' purport to state facts. But before examining this view, we pause to consider what exactly motivates Phillips to take such an approach to religious language. The answer may lie in Wittgenstein's criticisms of Frazer's Golden Bough. Wittgenstein, it will be recalled, objected that Frazer was treating the beliefs of magic and religion as though they were intended to be scientific truths that rested on empirical evidence. But, Wittgenstein argued, to treat magic and

40 Brown, Philosophy and the Christian Faith (Downers Grove, IL: InterVarsity Press, 1968), p.178. Cf. William Wainwright, “The Presence of Evil and the Falsification of Theistic Assertions,” Religious Studies 4 (1969): 215. 
religion in this way is to make these forms of life look stupid. For if magical and religious beliefs are evaluated by the same standards by which we assess scientific hypothesese.g., explanatory adequacy, predictive power, simplicity, fit with background knowledge - then the beliefs of magic and religion will inevitably turn out to be false:

Frazer's account of the magical and religious views of mankind is unsatisfactory: it makes these views look like errors.

Was Augustine in error, then, when he called upon God on every page of the Confessions?

The very idea of wanting to explain a practice - for example, the killing of the priest-king - seems wrong to me. All that Frazer does is to make them plausible to people who think as he does. It is very remarkable that in the final analysis all these practices are presented as, so to speak, pieces of stupidity.

But it will never be plausible to say that mankind does all that out of sheer stupidity. ${ }^{41}$

Unable to believe that the bulk of humanity could hold patently false or absurd views, Wittgenstein is led to conclude that people who are engaged in magic and religion are not offering a scientific view of the world based on evidence and conjecture, but are doing something quite different—and Wittgenstein saw it as his task to indicate just what those who participate in magic and religion are really up to.

Phillips' thinking, we suspect, follows a similar trajectory. In particular, Phillips’ philosophy of religious language seems to be motivated by the following line of reasoning: If theistic beliefs presuppose a conception of God as a metaphysically real subject—or a pure consciousness—-then such beliefs would be nonsense or unintelligible;

\footnotetext{
${ }^{41}$ Wittgenstein, "Remarks on Frazer's Golden Bough," in Wittgenstein, Philosophical Occasions: 19121951, edited by James C. Klagge and Alfred Nordmann (Indianapolis: Hackett Publishing Company, 1993), p.119, emphasis in the original (see also p.125).
} 
but belief in God is clearly not nonsense or unintelligible; hence theistic beliefs do not rest on a conception of God as a metaphysically real subject—or a pure consciousness. We have argued that Phillips' case in support of the main premise of this argument is fairly weak. But putting that aside, we can see why Phillips develops the kind of nonrealist account of religious language that will be outlined in the ensuing section. For if theists—-that is, theists not blinded by philosophical prejudices—do not think of God as a metaphysically real subject, then they must be thinking of God in some non-realist fashion. Although possible, it seems unlikely that Phillips would have taken up the nonrealist cause if he had no logical qualms with the metaphysically real God—just as Wittgenstein would not have taken up his critique of the Golden Bough had he thought that religious beliefs are not obviously false when viewed as empirical or fact-stating statements.

In closing this section, it is probably worth noting that there is a curious discrepancy between the Wittgensteinian account of "the magical and religious views of mankind", and the views Phillips holds about those who believe in a 'metaphysically real' God. When we turn our anthropological or sociological eye on, say, contemporary fundamentalist Christians in the United States, it seems that we are driven to the conclusion that there are millions upon millions of believers in a 'metaphysically real' God. There are, after all, thousands upon thousands of websites and printed works in which belief in a 'metaphysically real' God is expressed (and, though this is not relevant to our present point, examined and defended). On their own account—and as the vast weight of evidence attests—a huge number of these people really do believe that God brought the universe into existence a few thousand years ago, that God can be persuaded 
to intervene in human affairs by petitionary prayer, that God will take all of the deserving faithful to Heaven in the very near future while leaving the undeserving to continue to wander this Earth, and so forth. Moreover, these beliefs just are the core religious beliefs of these people: they pray because they believe that petitionary prayer is effective, etc. An anthropologist who fails to attribute 'metaphysical weight' to their religious beliefs just gets them wrong, even if-as Phillips supposes - the beliefs as thus interpreted are illusory, or confused, or downright 'unintelligible'. About these people, it seems that, on account of what is said elsewhere, Phillips and the other Wittgensteinians are committed to saying both that there is no intelligible content that can be given to the claims that these people make - their believing is "sheer stupidity"-and that it could never be plausible to claim that these people hold all of these beliefs "out of sheer stupidity”. At first sight—and, we think, not only at first sight—such a position is simply inconsistent: if belief in a 'metaphysically real' God is "sheer stupidity", then it is at best an empirical question whether the bulk of humanity is the victim of "sheer stupidity". 42

Phillips might here reply that there is a crucial distinction to be made between engaging in a form of life and providing a philosophical account of that form of life. Surely religious people can fail to give a proper philosophical account of their religious beliefs and practices —-whence, we cannot suppose that a 'Gallup poll' is a reliable guide to the content of those beliefs and the nature of those practices. But this response, even if applicable in some cases, seems entirely irrelevant to our present point. The claims that

\footnotetext{
${ }^{42}$ Of course, there is quite a bit of empirical research which suggests that, across a range of cases, the bulk of humanity is the victim of "sheer stupidity". Consider, for example, the research that shows how bad people typically are at statistical inference: they ignore base rates, they embrace the gambler's fallacy, and so on. So long as we are prepared to allow that these failures of reason typically do no very serious harmbecause, say, those who embrace the gambler's fallacy typically do not risk more than they can afford to lose- there is no evident barrier to the supposition that this evidence simply demonstrates that people very often are victims of "sheer stupidity".
} 
Phillips finds 'unintelligible’-e.g., that the world is just 6.000 years old, that there is an intelligent being that responds to petitionary prayer, and so forth-are manifestly not the elements of a philosophical account of the religious beliefs in question; rather, these claims just are the first-order religious beliefs in question. ${ }^{43}$ An anthropologist studying these people who arrives at the view that they do not believe in the literal efficacy of petitionary prayer-because to attribute that belief to them would be to burden them with “sheer stupidity"-is just not doing his job properly. And, the desperate pronouncements of some of the Wittgensteinian philosophers of religion notwithstanding, there is no reason why this point could not carry over to the vast majority—or even entirety—of the religious and magical beliefs and practices of human societies.

There is perhaps an alternative line of reply that Phillips might try. Consider, to begin with, Alan Keightley's remarks on the Wittgensteinian idea of 'genuine' or 'true' religion:

The Wittgensteinian conception of what genuine religion amounts to means that they do not claim to give an account of the entire range of belief and commitment we find that believers actually have. However, as the Wittgensteinians would probably say themselves, the language of the kind of religion they admire is in decline. ${ }^{44}$

In line with this view, Phillips might say that it is perfectly in order to hold that the vast bulk of humankind is engaged in religious and magical practices out of "sheer stupidity", but that it is not in order to suppose that those who are engaged in 'genuine' - 'properly

\footnotetext{
43 Anyone who says otherwise is obviously in the grip of a philosophical theory.
} 
ordered'—religious and magical practices do so out of "sheer stupidity”. But, of course, this immediately prompts a range of questions about the identification of 'genuine' religious and magical practices. Phillips might be inclined to claim that 'genuine' religious and magical practices have some affinity with mysticism and negative theology: we proceed aright so long as we insist that there is no way of saying what is the literal content of religious and magical beliefs. However, if that is the sole remaining 'out', then we're inclined to say that what is left is just another form of "sheer stupidity": it is remarkable how much drivel is produced by mystics and negative theologians who simultaneously claim that there really is nothing that can be said about what it literally is that they believe. As Tom Lehrer (more or less) has it, the very least that those who think they are unable to communicate what it is that they believe can do is to shut up. If you think that you cannot give literal expression to what it is that you believe, then whistling in the dark is not going to help; on all sides, it will be far better if you simply pass by in silence. $^{45}$

\section{Is Religious Language Fact-Stating?}

Phillips, following the later Wittgenstein, often describes religious beliefs as forming distinctive 'language games’. Occasionally, however, Phillips expresses some misgivings

\footnotetext{
${ }^{44}$ Keightley, Wittgenstein, Grammar and God, p.160.

45 A less tendentious way of making our point here is to say that there is a very strong case for saying that, contra the claims of the Wittgensteinians, it is the language of mysticism and negative theology that is "language in decline".
} 
about this characterisation. ${ }^{46}$ For one thing, a 'game' suggests something frivolous or hobby-like, whereas religious beliefs have momentous significance and value, at least for those who accept such beliefs. More importantly, treating religious belief as a distinct language game has often raised the suspicion that any given religious tradition would then become a self-contained esoteric game having its own criteria of truth, rationality, and intelligibility, thus rendering it immune from criticism 'from without'. Religious belief, on this view, becomes a form of fideism— 'Wittgensteinian fideism', to use Kai Nielsen's phrase. ${ }^{47}$ In attempting to meet this criticism, Phillips points out that religious language games should not be thought of as being entirely cut off from non-religious language games and other aspects of human life. There are important connections between religious and non-religious forms of life, and these must be recognised if religious belief is not to degenerate into superstition. If, for example, a religious believer talks of death as if it were a sleep of long duration, one may accuse her of not taking death seriously, and this criticism is drawn from what we already know and believe about these matters. ${ }^{48}$ But despite these connections between the religious and non-religious

\footnotetext{
${ }^{46}$ See, for example, Phillips, "Religious Beliefs and Language-Games," in his Faith and Philosophical Enquiry (London: Routledge \& Kegan Paul, 1970), ch. 5.

${ }^{47}$ Kai Nielsen, “Wittgensteinian Fideism,” Philosophy 42 (1967): 191-209.

${ }^{48}$ Phillips offers this and other examples in "Religious Beliefs and Language-Games,” p.98 (the distinction between religion and superstition is elaborated further on pp.101-109). See also Phillips, Belief, Change and Forms of Life, ch. 1, and Religion and the Hermeneutics of Contemplation (Cambridge: Cambridge University Press, 2001), pp.25-30, where he argues vigorously against the equation of his views with Wittgensteinian fideism.

That Phillips does not think of religious language games as entirely divorced from, or incommensurate with respect to, other language games is often missed by his critics - see, for example, Joseph Runzo, “Realism, Non-Realism and Atheism: Why Believe in an Objectively Real God?” in Runzo (ed.), Is God Real? pp.159-60. A critic who has not overlooked this aspect of Phillip's thought is Lance Ashdown, who argues nevertheless that Phillips' position that religious language games are not completely autonomous does not cohere well with his repeated insistence that philosophers ought to stop judging religious beliefs on the basis of criteria borrowed from non-religious forms of discourse (see Ashdown, "D.Z. Phillips and his Audiences,” Sophia 32 (1993): 1-31). See, however, Phillips, Religion and Friendly Fire, pp.8-11, where Phillips attempts to meet a similar criticism made by Stephen Mulhall.
} 
domains, Phillips emphasises that the distinctiveness of religious belief must not be overlooked. In particular, the language of religious believers must not be assimilated to the kind of fact-stating, physical-object discourse that characterises the empirical sciences.

Phillips' account of religious language may be elucidated by looking at the kind of view it stands in opposition to. The opposing view-accepted, incidentally, by the majority of contemporary analytical philosophers of religion—holds that theistic beliefs purport to express 'facts' that are objective in some important sense. More precisely, theistic beliefs are thought to be true or false, and their truth-value is taken to be completely independent of what any human being thinks or believes. This, indeed, is just what realism with respect to religious belief amounts to. As Hick explains,

Religious realism is the view that the existence or non-existence of God is a fact independent of whether you or I or anyone else believes that God exists. If God exists, God is not simply an idea or ideal in our minds, but an ontological reality, the ultimate creative power of the universe. ${ }^{49}$

But if theistic beliefs express facts, then their truth or falsity can be discovered by us, and many philosophers of religion believe that the projects of natural theology and natural atheology play an important role in this respect. Richard Swinburne and Michael Martin, for example, have devoted lengthy studies to the question of the existence of God, and

${ }^{49}$ Hick, "Believing-And Having True Beliefs," in Runzo (ed.), Is God Real? p.115. Cf. Stephen T. Davis' first two definitions of religious realism in God, Reason and Theistic Proofs (Edinburgh: Edinburgh University Press, 1997), pp.47-48. 
the approach of each philosopher has involved the accumulation and evaluation of various pieces of evidence both for and against theistic belief. ${ }^{50}$

Phillips is adamant that this way of proceeding is entirely mistaken. In one of his early papers, for example, he writes:

Because the question of divine reality can be construed as 'Is God real or not?' it has often been assumed that the dispute between the believer and the unbeliever is over a matter of fact. The philosophical investigation of the reality of God then becomes the philosophical investigation appropriate to an assertion of a matter of fact. That this is a misrepresentation of the religious concept is made obvious by a brief comparison of talk about facts with talk about God. ${ }^{51}$

Fact-stating language, Phillips goes on to note, has the following characteristics. (1) When claiming something to be a 'fact', we typically presuppose that we are not entirely sure or certain that what we are stating is indeed the case:

When do we say, 'It is a fact that...' or ask, 'Is it a fact that...?'? Often, we do so where there is some uncertainty. For example, if the police hear that a wanted criminal has died in some remote part of the world, their reaction might be, 'Check the facts'. ${ }^{52}$

(2) Fact-stating discourse, furthermore, has a contingent character, for it expresses truths that might have turned out to be false: "A fact might not have been: it is conceivable that

\footnotetext{
50 See Richard Swinburne, The Existence of God, rev. ed. (Oxford: Clarendon Press, 1991), and Michael Martin, Atheism: A Philosophical Justification (Philadelphia, PA: Temple University Press, 1990).

${ }^{51}$ Phillips, "Philosophy, Theology and the Reality of God," in Faith and Philosophical Enquiry, p.1, emphasis in the original.

${ }^{52}$ Ibid.
} 
the wanted criminal had not died." ${ }^{\text {53 }}$ (3) Given the contingent nature of facts, the language of facts is only appropriate when the subject-matter concerns contingent reality, such as physical properties or objects that come into being and pass away. (4) Finally, we have procedures in place for resolving disputes regarding matters of fact, and these procedures usually involve looking to the truth or falsity of other matters of fact. In all these respects, according to Phillips, the language of facts diverges from the language of religion.

Re (1): Phillips says that believers are not tentative in, or uncertain of, their (religious) beliefs. They would not, for example, think of the reality of God as a conjecture or hypothesis that stands in need of proof or evidence. Phillips is therefore scathing of those, like Swinburne and Mackie, who like to apply the probability calculus to the question of the existence of God. He characterises such philosophers as "the friends of Cleanthes”, referring of course to Hume's character, Cleanthes, who also enquired into God's existence by asking whether God can be probabilistically inferred from the nature or existence of the world. Phillips counsels his readers to "give up bad philosophical friends, among them the friends of Cleanthes," for they distort the nature or underlying 'grammar' of religious belief:

If religious beliefs are matters of probability, should we not reformulate religious beliefs so that the natural expressions of them becomes less misleading? Should we not say from now on, 'I believe that it is highly probable that there is an almighty God, maker of heaven and earth?'; 'I believe that it

53 Ibid., pp.1-2. 
is highly probable that my Redeemer liveth'; 'I believe that it is highly probable that God forgives sins'? Do these reformulations do justice to the nature of religious beliefs? Hardly. ${ }^{54}$

The reality of God, rather, functions as a 'bedrock' belief in the religious language game, a belief which informs an entire way of life without itself being subject to confirmation, disconfirmation or doubt. Unlike matters of fact, where we do not regard it wrong or bad to raise doubts, doubt regarding God's existence is not merely out of place, but sinful (analogously, faith is called a virtue). ${ }^{55}$ Holding religious beliefs, then, "has little in common with any kind of conjecture. It has to do with living by them, drawing sustenance from them, judging oneself in terms of them, being afraid of them, etc.”56

${ }^{54}$ Phillips, "The Friends of Cleanthes: A Case of Conceptual Poverty," in Phillips, Recovering Religious Concepts: Closing Epistemic Divides (Basingstoke: Macmillan, 2000), p.64. See also Phillips, "In All Probability,” Times Literary Supplement, 28 May 1982, p.588, where he reviews Swinburne's Faith and Reason and takes him to task for holding that belief in God is belief in what is merely probable.

55 See Phillips, Religion Without Explanation (Oxford: Basil Blackwell, 1976), pp.174-75, where he draws upon some remarks by Rhees and Wittgenstein.

${ }^{56}$ Phillips, Death and Immortality, p.68. A similar point is made in a discussion Phillips had with J.R. Jones on BBC radio (which was first published in 1970):

JRJ.: What is it that shows that, to take Wittgenstein's example, belief in the Last Judgment has obviously nothing in common with a hypothesis?

DZP: I think that if we do look at the role this belief plays in at least many believers' lives, we find that it is not a hypothesis, a conjecture, that some dreadful event is going to happen so many thousands years hence. We see this by recognizing that a certain range of reactions is ruled out for the believer. What I mean is this: if it were a conjecture about a future event, he might say, 'I believe it is going to happen' or 'Possibly it might happen' or 'I'm not sure; it may happen', and so on. But that range of reactions plays no part in the believer's belief in the Last Judgment.

(“Belief and Loss of Belief,” in Phillips, Faith and Philosophical Enquiry, pp.112-113.)

On the 'bedrock' nature of religious belief, see also Phillips, Religion Without Explanation, ch. 10, where Phillips notes that the proposition 'God exists' "does not get its unshakeable character from its inherent nature, or from the kind of abstraction which philosophy tries to make of it so often, but from its surroundings, from all the activities that hold it fast. Above all, those activities involving the language of praise and worship" (p.172).

We should also point out that, on Phillips' view, the firmness of a religious belief does not mean that it cannot be renounced. For Phillips, however, what erodes religious faith is not evidential considerations (such as evidential arguments from evil), but factors such as the appeal of a rival secular outlook or more 
Re (2): Phillips says that, unlike facts, religious beliefs do not express contingent truths. We might be prepared to say that it might not rain tomorrow, but "the religious believer is not prepared to say that God might not exist."57

Re (3): Phillips says that, if God is not something that might or might not exist, then God cannot be thought of as an object, a thing, or a being existing amongst other beings. Indeed, the life-transforming impact that the reality of God is often said to have indicates that God cannot properly be described as an object:

Coming to see that there is a God is not like coming to see that an additional being exists. If it were, there would be an extension of one's knowledge of facts, but no extension of one's understanding. Coming to see that there is a God involves seeing a new meaning in one's life, and being given a new understanding. The Hebrew-Christian conception of God is not a conception of a being among beings. $^{58}$

Discovering the existence of an object (say, a further planet in our solar system) would result in an extension to our current body of knowledge, but such a discovery—unlike a conversion to religious belief-would not radically alter the character of one's personal life. Accepting God is quite unlike accepting the existence of some physical object. Talk

pervasive cultural changes. See Phillips, "Belief and Loss of Belief,” p.116, Death and Immortality, pp.7376, and Belief, Change and Forms of Life, pp.86-93.

57 Phillips, "Philosophy, Theology and the Reality of God,” p.2.

${ }^{58}$ Phillips, "Faith, Scepticism, and Religious Understanding," in Phillips, Faith and Philosophical Enquiry, pp.17-18. Phillips makes a similar point in response to Hick's procedure of pointing to religious believers who say that the existence of God is a matter of fact: "I have no doubt, however, that the same believers who say that the existence of God is a fact would, if pressed, admit that the discovery of God is not like the discovery of a matter of fact" ("Religious Belief and Philosophical Enquiry," in Phillips, Faith and Philosophical Enquiry, p.71, emphasis in the original). 
of God, then, cannot to be modelled on talk about physical objects. ${ }^{59}$ Phillips’ point, as

Scott and Moore explain, is that "one cannot, by qualifying, explaining or extending the forms of expression one uses with regard to physical objects, reach an appropriate form of expression for talking about God.” ${ }^{60}$ It is misleading, however, not only to speak of God as an 'object', but to even speak of him as an 'existent', for our notion of existence carries with it an implication of contingency: ordinarily, one cannot say that something exists unless it makes sense to suppose that it might not have existed. Phillips therefore prefers to say, along with Kierkegaard, that "God does not exist, He is eternal."61 Since God does not belong to the order of contingent reality, our language about God should not be assimilated to our way of speaking about common (or contingent) objects, beings, or existents. The word 'God', Phillips states, "is not the name of an individual; it does not refer to anything."62

59 See Phillips, The Concept of Prayer (London: Routledge \& Kegan Paul, 1965), pp.21-23.

${ }^{60}$ Michael Scott and Andrew Moore, “Can Theological Realism Be Refuted?” Religious Studies 33 (1997): 414. As Scott and Moore note (in their fn.18, p.414), Phillips assumes that the religious realist suffers from the 'philosophical prejudice' that non-physical reality can be understood on analogy with physical reality. Phillips, to be sure, has further criticisms of this prejudice than those indicated in the main text. He argues, for example, that our criteria of individuation for (empirical) objects are not the same as those we have for God, and that accurate depictions of objects can be constructed, but no such images of God are available. For criticisms of these arguments, see Scott and Moore, op. cit., pp.414-18.

${ }^{61}$ The quote is taken from Kierkegaard's Concluding Unscientific Postscript, trans. David F. Swenson (Princeton, NJ: Princeton University Press, 1941), p.296. Phillips often approvingly quotes this remarksee, for example, "Faith, Scepticism, and Religious Understanding," p.18; Faith After Foundationalism (London: Routledge, 1988), p.229; and "Philosophers' Clothes” in Charles M. Lewis (ed.), Relativism and Religion (New York: St. Martin’s Press, 1995), p.138.

${ }^{62}$ Phillips, Religion Without Explanation, p.148. Cf. Phillips, "Religious Beliefs and Language-Games,” p.85. Phillips would not want to deny, however, that 'God' is in some sense a referring expression, but he would add that the sense in which 'God' is taken as a referring expression needs to be made clear (see Phillips, "Philosophers' Clothes,” p.138). As Rhees puts it, "I might say that the language about God certainly does refer to something. But then I should want to say something about what it is to 'talk about God', and how different this is from talking about the moon or talking about our new house or talking about the Queen. How different the 'talking about' is, I mean. That is a difference in grammar" (Without Answers, London: Routledge \& Kegan Paul, 1969, p.132). 
Re (4): Finally, Phillips says that disagreements between believers and unbelievers cannot be settled in the way in which we resolve factual disputes. Disagreements over facts usually take place against a background of shared beliefs, so that there is little or no disagreement as to (e.g.) what counts as a fact and what kind of evidence or investigation is relevant to settling a particular dispute over a matter of fact. If, for example, someone claims that there is a certain species of bacteria on the table when in fact there are none there, we can at least agree as to what kind of evidence or investigation would settle the issue. Disputes amongst believers and unbelievers, however, lack any such background of shared beliefs. As a result, there is no commonly accepted decision procedure for adjudicating cases where, for example, one claims to be perceive (or experience) God and another claims that the perception is illusory. As Phillips states,

When the positivist claims that there is no God because God cannot be located, the believer does not object on the grounds that the investigation has not been thorough enough, but on the grounds that the investigation fails to understand the grammar of what is being investigated - namely, the reality of God. ${ }^{63}$

Putting together the above four points of divergence between factual discourse and religious discourse, Phillips concludes that religious beliefs are not statements of fact, but confessions of faith. ${ }^{64}$

\footnotetext{
${ }^{63}$ Phillips, "Philosophy, Theology and the Reality of God," p.2.

${ }^{64}$ One may, of course, speak of 'religious facts', but in that case, Phillips notes, "all the grammatical work has still to be done. We have to show how talk of facts in this context differs from talk of facts in other contexts. We would need to be clear about what finding out the facts, discovering the facts, or being mistaken about the facts, would amount to where religious matters are concerned. There would be similarities enough with other contexts, but there would be huge differences. I suspect what is important
} 
How plausible is Phillips' view of religious language as non-fact-stating? We believe that Phillips' position falls far short of a philosophically satisfying account of the nature of religious belief. In particular, we think that Phillips' account relies on a superficial view of the different claims that are made by religious believers. At least in part, our reasons for saying this can be exhibited in a reconsideration of the four purported disanalogies between fact-stating language and religious language that are identified by Phillips.

Consider, firstly, Phillips' claim that religious beliefs, unlike factual statements, are not tentative or conjectural in nature and do not require confirmation by way of proof or evidence. It is difficult to determine whether Phillips is here advancing a descriptive claim—this is just how religious beliefs are normally held—or a normative claim—this is how religious beliefs should be held—or both. ${ }^{65}$ But, however his claim is best interpreted, it is mistaken. Descriptively construed, Phillips' claim stands refuted, or is at least challenged, by the fact that there has always been a significant group of believers who have sought to construct a rational case in support of their religious beliefs. One can find, for example, a reasoned defence of the fundamental tenets of the Christian faith in many of the 'apologists' of the early Christian centuries (including Aristides, Justin Martyr, and Athenagoras of Athens), numerous patristic writers (such as Gregory of Nyssa and John of Damascus), scores of theologians in both east and west during the

would lie in these differences” (Faith After Foundationalism, p.230). As pointed out in fn. 61 above, Phillips makes a similar point in regards to calling God an object or 'God' a referring expression.

${ }^{65}$ Given that Phillips often extols Wittgenstein's principle of 'leaving everything as it is' as an ideal to which philosophers of religion should aspire (see, e.g., Phillips' paper, "Religion in Wittgenstein's Mirror," in Wittgenstein and Religion, Basingstoke: Macmillan, 1993, pp.237-55), it would seem that Phillips is advancing a descriptive rather than a normative claim. Such an approach may be contrasted with the explicitly revisionary non-realism advocated by Don Cupitt in Taking Leave of God (London: SCM Press, 1980). 
Middle Ages (Thomas Aquinas being the prime example), and many contemporary philosophers and theologians (Richard Swinburne and William Lane Craig, for example). To be sure, these thinkers do not claim that the only or the best way to arrive at religious belief is through philosophical argumentation. Still, they do regard natural theology or 'positive apologetics' (the project of offering arguments in support of religious belief without recourse to divinely revealed truths) and 'negative apologetics' (the project of rebutting objections to religious belief) as crucially relevant to the life and practice of the church. There is, therefore, an important strand within Christianity—and the other major theistic traditions - that treats religious belief as something that is subject to confirmation and disconfirmation. This is not to ignore the fact that within Christianity one will also find opposing streams of thought which are more sympathetic to Phillips' account of religious belief—-the apophatic and mystical traditions are cases in point. But what this indicates is that Christianity, like any of the major world religions, is not a homogeneous entity, but displays an enormous variety of views about the nature and meaning of religious language. Any simple descriptive claim, such as ‘religious believers do not base their beliefs on evidence', will therefore be misleading at best and patently false at worst. ${ }^{66}$

\footnotetext{
${ }^{66}$ However, as Richard Messer points out, the various conceptions of God and the competing views on the nature of religious belief that exist within historical Christianity "overcome the simple charge that Phillips is a revisionist; for there is no single dominant conception of God, even within Christianity, to be revised" (Does God's Existence Need Proof? p.55).
} 
Phillips is no doubt aware of the diversity that exists within the theistic tradition ${ }^{67}$, but it is difficult to see how he could plausibly respond. He might reply, for example, that the 'proofs' of theologians such as Anselm and Aquinas are not aimed at substantiating the belief that God exists, but are rather exercises in 'faith seeking understanding', this being the attempt to understand what is already believed, as opposed to understanding in order to believe. ${ }^{68}$ But this seems a dubious interpretation of what natural theologians, both past and present, are doing when constructing theistic arguments. For if their aim is merely to understand, and not to substantiate or persuade, then a carefully structured argument containing various premises and concluding with 'God exists' would be a most peculiar way to achieve such an aim.

Alternatively, Phillips might reply that natural theologians are an aberrant group of philosophers who attempt to import into religious practice an alien form of thinking, typically one informed by metaphysical speculation or scientific reasoning. But now Phillips would be resorting to a normative judgment—regarding the proper way religious beliefs are to be held — and here he is on weaker ground still. There might be some reason to think that natural theology was not necessary or vitally important during the Middle Ages, given that the existence of God was rarely in dispute amongst intellectual circles and in the wider community. But today, as in the early Christian centuries, the situation is quite different. Belief in God is under attack from various quarters: scientists and

\footnotetext{
${ }^{67}$ For example, in response to John Hick's fact-stating account of religious belief, Phillips writes: “One has a vast and various range of persons, all claiming to be religious believers. I do not deny, then, that there are people whose conception of God is similar to that outlined by Hick" ("Religion and Epistemology: Some Contemporary Confusions," in Faith and Philosophical Enquiry, p.127). And later on, he writes: "I do not wish to defend those people whose religious beliefs can be described adequately in Hick's terms. I only wish to stress that there is another kind of belief in God” (p.129).

${ }^{68}$ See Phillips, "Sublime Existence" in Wittgenstein and Religion, p.10, and "Return of the Monstrous Illusion” in Recovering Religious Concepts, p.19.
} 
scientifically-minded philosophers often claim that all natural phenomena can be adequately explained without invoking the 'God hypothesis'; in line with this view, a number of naturalistic accounts of the genesis and spread of religious belief have been offered, with belief in God portrayed as the product of ignorance and fear in the face of the hostile forces of nature (Hume), or an inequitable social order (Marx and Engels), or an immature or infantile psychology (Freud); the historical reliability of the scriptures that theists claim to be divinely inspired has been placed in question; and we are now more aware of the diversity of religious belief across the world's races and nations. Arguably, in times like these, theists who are apprised of the contemporary challenges faced by religious belief ought not accept the existence of God without at least attempting to meet some of the objections levelled against theism, and perhaps also attempting to find some evidence in support of theism. ${ }^{69}$ Concomitantly, it can be argued that the only type of religious faith that is appropriate for today's well-informed theists is one that is modest and tentative, not dogmatic and self-assured.

Robert McKim, a contemporary theist, has forcefully argued in support of this conception of religious faith. ${ }^{70}$ McKim states that theists must acknowledge both the hiddenness of God (i.e., the fact that the reality of God is not obvious to many people) and the widespread diversity in religious belief amongst people of seemingly equal integrity and competence. In the face of these phenomena, argues McKim, the only

\footnotetext{
69 A position of this sort has been defended by David Basinger, "Plantinga, Pluralism and Justified Religious Belief," Faith and Philosophy 8 (1991): 67-80, and Philip L. Quinn, "The Foundations of Theism Again: A Rejoinder to Plantinga,” in Linda Zagzebski (ed.), Rational Faith: Catholic Responses to Reformed Epistemology (Notre Dame, IN: University of Notre Dame Press, 1993), pp.35-45.

${ }^{70}$ See Robert McKim, Religious Ambiguity and Religious Diversity (Oxford: Oxford University Press, 2001), esp. chs 7-9.
} 
appropriate response is the adoption of a 'Critical Stance'. To adopt this stance towards

one's beliefs is to critically examine one's beliefs in the light of objections and

conflicting evidence, and to hold one’s beliefs in a tentative manner, always open to the

prospect that one is mistaken. ${ }^{71}$ As McKim puts it,

Religion in accordance with the Critical Stance is religion that is conducted more in the mode of longing and aspiration than in the mode of confident declaration. It has progressed from "knowing" that it is right to acknowledging how limited is our ability to know about religious matters, and to recognizing both the ambiguity of our circumstances and the variety of responsible responses to those circumstances. ${ }^{72}$

Despite the fears of some religious believers, re-envisioning religious faith in the way suggested by McKim may well be a move in the right direction, an advance of some sorts, for the practice of religion. For we all know what happens to religious (and non-religious) people who do not seek to provide reasons in support of their fundamental commitments and refuse to subject their beliefs to critical scrutiny: they become intolerant, selfrighteous 'fundamentalists'. 73

\footnotetext{
${ }^{71}$ For McKim, however, tentativeness includes more than the mere recognition of one's fallibility: "tentative belief that $\mathrm{p}$ is belief that $\mathrm{p}$ is true that involves an awareness that $\mathrm{p}$ may need revision, and may even be false, and that there may be viable alternatives to $\mathrm{p}$. It involves openness to inquiry and openness to change, and it may involve ongoing inquiry and experimentation” (Religious Ambiguity and Religious Diversity, p.158).

${ }^{72}$ McKim, Religious Ambiguity and Religious Diversity, p.142.

${ }^{73}$ This, however, gives rise to a problem which, we suspect, motivates much of what Phillips has to say on the non-conjectural nature of religious belief: How can religious belief be held tentatively on the basis of (somewhat flimsy) evidence while at the same time providing the basis for an unconditional and passionate commitment (to God)? For some proposals as to how tentative religious belief can be reconciled with, and even inform and heighten, religious commitment, see McKim, Religious Ambiguity and Religious Diversity, pp.166-70, and C. Stephen Evans, Philosophy of Religion: Thinking About Faith (Downers Grove, IL: InterVarsity Press, 1982), pp.171-76.
} 
Phillips' second purported disanalogy between fact-stating discourse and religious language is that, whereas facts express contingent truths, the truths upheld by religious believers are not of the kind that could turn out to be false. But this view is mistaken on two counts. Firstly, it is not clear why facts cannot express necessary truths. We might, for example, speak of 'mathematical facts', or we might think—along with Kripke and others - that it is a fact that water is $\mathrm{H}_{2} \mathrm{O}$ even though it is necessarily true that water is $\mathrm{H}_{2} \mathrm{O}$. And secondly, even if all facts are contingently true, many theists are quite prepared to hold that the existence of God is a contingent truth. Indeed, it would be rare to find a theist who views theism as necessarily true—-for one would require something to the effect of a sound ontological argument to support such a view. But theists are often prepared to accept that there are possible worlds in which God does not exist, or that there is some conceivable evidence that would falsify their belief in God. Such theists, however, need not think that God is dependent in any way for his existence on something outside himself, or that God might exist at one time but cease existing at some future time. In other words, one may hold that 'God exists' expresses a contingent truth, while at the same time holding that God is ontologically independent (or has the property of aseity) and is eternal or everlasting. ${ }^{74}$

Phillips' third disanalogy is that, whereas factual discourse is intended to refer to objects in the world, discourse about God is not intended to refer to any object or thing at all. Admittedly, there are contexts in which it is improper to describe God as an 'object';

\footnotetext{
${ }^{74}$ The above discussion is premised on the assumption that the kind of necessity in question is logical. As Richard Swinburne points out, this sense of necessity—i.e., logical necessity-is not always the kind of necessity that is attributed to God. Rather, God's existence is often thought to be 'necessary' only in the sense that God does not depend for his existence on himself or on anything else. See Swinburne, The Coherence of Theism, pp.263-68.
} 
namely, those contexts in which 'objects' are taken to contrast with 'subjects', or 'centres of consciousness', or 'persons', or the like. But there are many contexts in which it is perfectly legitimate to call minded beings, such as a human persons or gods, 'objects'. As Swinburne states,

If you mean [by saying of God that he is an object] God is something of which properties are true, which causally interacts with other recognisable observable objects, which can be distinguished from others as the subject of certain predicates which he has and they don't: well, that is the case with God, and therefore on any natural understanding of 'object', God is an object. ${ }^{75}$

Phillips maintains, however, that the reality of God is not logically akin to the reality of an object. As mentioned earlier, Phillips attempts to support this view by arguing that, if God could be thought of as an object, then ‘discovering God'—as happens in religious conversions-would have the same effect as discovering some fact or the existence of some physical object; that is to say, there would merely be an extension to one's body of knowledge without any corresponding change in one's outlook on the world or one's way of life. But the discovery of a fact or an object can, and often does, radically alter one's worldview or way of life. Consider, for example, how any of the following could lead one to see life in an entirely different light: discovering a million dollars in your garden, discovering that your partner has died in a car crash, discovering that your partner has cheated on you, discovering that you have only ten years to live, discovering that you have been adopted, and so on. There is no reason why the discovery of a fact cannot be an extension to one’s knowledge and a life-changing experience.

${ }^{75}$ Quoted in Messer, Does God's Existence Need Proof? p.21. 
However, Phillips also holds that objects are unlike God in that objects can be said to exist, whereas the sentence 'God exists' is somewhat peculiar and inappropriate as a vehicle for the expression of religious belief. For, in Phillips' view, to say that God exists is to imply that God exists contingently ${ }^{76}$ But, according to Phillips, God's reality is of a different order altogether: it makes no sense to say that God might not have existed or to ask such questions as: 'How long has God existed? Will he still exist next week? He was in existence yesterday, but how about today? ${ }^{77}$ The underlying assumption that Phillips makes here may be put as follows: If something $x$ exists, then (a) it is possible for $x$ to not exist, and (b) it is possible for $x$ to come into existence and cease existing. But what reason is there to accept this? There does not appear to be any conceptual impossibility in the idea of something which cannot fail to exist and cannot come into being and pass away. For one thing, a host of abstract objects—e.g., numbers, sets, properties—have been accorded this distinction. And there does not seem to be any conceptual barrier in saying the same thing of a concrete object, such as a divine being. ${ }^{78}$

\footnotetext{
${ }^{76}$ This view is egregious, though Phillips is not the only philosopher to have endorsed it. It is an uncontroversial modal claim that whatever is necessarily so is so. Whence it follows that, if God necessarily exists, then God exists. But, give Phillips his claim that 'God exists' entails 'It is contingently true that God exists', and we get out the absurd view that 'It is necessarily true that God exists' entails 'It is contingently true that God exists'. This is one point where Grice can help. Clearly, if you hold that it is necessary that God exists, then there will be many contexts in which you ought not to assert merely that God exists-for, if you say only that God exists, there is a clear conversational implicature that you do not suppose that God necessarily exists (given that the Gricean conversational maxims are in place).

77 Cf. Norman Malcolm, “Anselm’s Ontological Arguments,” Philosophical Review 69 (1960): 49.

${ }^{78}$ For a similar criticism of Phillips, see Stephen Davis, God, Reason and Theistic Proofs, p.53. In his paper "Sublime Existence” (collected in his Wittgenstein and Religion), Phillips mentions Kierkegaard's remark that 'God does not exist, he is eternal', and then goes on to describe some similar views upheld by Simone Weil, John Wisdom, and Norman Malcolm—-however, Phillips then proceeds to criticise such views on the grounds that they "sublime the logic of 'existence', assuming that we can only ascribe 'existence' to things which come to be and pass away” (p.14). But isn't Phillips himself guilty of the same charge? We don't think so. Phillips explains that to sublime the logic of our language (a phrase borrowed from Wittgenstein) is to take language out of its contexts of application (p.12). Perhaps, then, Phillips' point is merely that, within religious contexts, God can be said to exist, though he cannot be said to exist
} 
Phillips' fourth disanalogy is that we have commonly accepted methods for resolving disputes over matters of fact, but there are no such methods for settling disputes between believers and non-believers. Unfortunately, there is much truth in this, for in disputes over the existence of God—and philosophical matters generally—arguments that convince, or at least ought to convince, both parties to the dispute are difficult to come by, and when they are found their compelling character is not easily recognised. This, no doubt, is partly because the disputing parties often have widely divergent background beliefs with respect to, e.g., the proper methodology to be employed, what the criteria of success should be, the admissibility of certain items of evidence, and various conceptual and factual matters. ${ }^{79}$ Hence the persistence of disagreement amongst believers and nonbelievers. We may lament this state of affairs, but it is no cause for supposing that there is no fact of the matter as to whether there is a God. Otherwise, we would be led to the unpalatable view that where there is widespread disagreement or dissent over the truth of $A$ and the proper way to determine the truth of $A$, there is no objective, non-relative truth regarding $A$ to be had. Surely, the mere contingent fact of disagreement should have no such far-ranging metaphysical implications.

Apart from these particular points, there are some more general considerations to which attention ought to be paid. Phillips places great weight on the idea that believers will not accept that it might be the case that God does not exist. But, we think, here—as

contingently. Phillips would no doubt add, however, that if God were thought to be an object, then God would be reduced to a contingent being, and it is this we wish to dispute.

${ }^{79}$ Cf. J.J.C. Smart, “Why Philosophers Disagree,” Canadian Journal of Philosophy suppl. vol. 19 (1993): 67-82. 
elsewhere-Phillips is content with a quite superficial view of what it is that believers will and won’t accept. It is well-known that the common modal terms can be used to express a great range of different modalities, and that contextual features play a very important role in determining which of the range of modalities is expressed by a given use of a modal term. So, in the case at hand, we can—and should—ask: in what sense, exactly, do Phillips' believers deny that it might be that God does not exist? Are they saying that it is logically—metaphysically, alethically—necessary that God exists? Are they saying that God's existence is entailed by what everybody knows? Are they saying that there is no sense to be made of the worldviews of those who do not accept the claim that God exists? Are they saying that it is irrational to adopt a worldview that makes no room for the claim that God exists? Are they saying that it is absolutely certain that God exists? Are they saying that they possess evidence which is such that the truth of that evidence entails that God exists? Or what? Without some further precisification, there is no serious theoretical work that can be done by the observation that Phillips' believers deny that it might be that God does not exist.

Another general point that deserves further attention is that the data to which Phillips appeals in order to motivate his claims about the non-factual nature of religious assertion can all be accommodated—and, in our view, much better accommodated—by the Gricean theory of conversation. Following Phillips-more or less—we can agree that, in many contexts, the point of making a claim of the form 'It is a fact that $p$ ' is to seek or to express agreement that the claim that $p$ is not open to serious dispute given the current conversational context. If that's right, then—on the Gricean theory—we would expect that one would typically make a claim of the form 'It is a fact that $p$ ' in circumstances in 
which there is some genuine reason to be uncertain whether it is a shared belief that the claim that $p$ is not open to serious dispute given the current conversational context. But, of course, if this is right, then—contra Phillips—-there is no reason at all to suppose that typical claims of the form 'It is a fact that $p$ ' take as their subject-matter only that which is logically—metaphysically, alethically—contingent. It is not hard to imagine a context in which it would be perfectly appropriate — and, indeed, correct— to say that it is a fact that arithmetic is not recursively axiomatisable (even though, of course, it is not merely a contingent truth that arithmetic is not recursively axiomatisable). Moreover, while it is clear that, on the Gricean account, there will be many contexts in which it would be inappropriate for religious believers to say that it is a fact that God exists—since there are many conversational contexts in which all of the participants take it to be common knowledge that God exists and there are also many conversational contexts in which it is recognised by all concerned that there is deep-rooted disagreement about whether God exists—it is also clear that, as the Gricean theory predicts, there are many conversational contexts in which it is perfectly appropriate for religious believers to assert that it is a fact that God exists, e.g., contexts in which it is simply uncertain whether all of the parties to the conversation accept the claim that God exists. And, of course, there are similar points to be made about assertions that God exists: there are conversational contexts in which such assertions are appropriate, and there are conversational contexts in which such assertions are inappropriate, given the conversational purposes at hand.

While there is more to be said about the details of Phillips' view and about the general considerations that bear on that view, we think that it is quite clear that there is no good reason to accept Phillips' view that religious language is not fact-stating. While we 
can happily acknowledge that there are many different things that are done by way of the making of religious utterances, we reject the suggestion that no religious utterances have, in part, the function of making assertions, or stating (purported) facts. Moreover, we think that it is equally clear that a very large amount of religious utterance, religious assertion, and religious belief does involve commitment to a 'metaphysically real' Godthe vast majority of religious believers do, in fact, suppose that their religious beliefs answer to an independent and transcendent reality. If there is no God, then, indeed, Augustine was in error when he called upon God on every page of the Confessions. ${ }^{80}$

${ }^{80}$ We would like to thank Stephen T. Davis for providing helpful comments on an earlier draft of this paper. 